\title{
Impact of Employee Empowerment and Perceive Organizational Support on Organizational Commitment in banking sector of Pakistan
}

\author{
[Muhammad Adnan Ashraf]
}

\begin{abstract}
The purpose of current study is to examine the impact of Employee Empowerment (EE) and Perceived Organizational Support (POS) on Organizational Commitment (OC) in workforce of banking sector in Pakistan. The data was gathered from randomly selected employees of Allied Bank Limited by using questionnaire. Data was collected within two months from sample of 153 respondents. Results showed that POS has strong influence on OC while EE has positive relation with $\mathrm{OC}$ but has weak influence on $\mathrm{OC}$ in banking sector of employees under this study. Moreover, this research is also beneficial for the management of Allied Bank limited that if they want to reduce the employee turnover rate and to create more committed employees.
\end{abstract}

Keywords - Organizational Commitment, Employee Empowerment, Perceived Organizational Support

\section{Introduction}

In order to survive, every organization needs to adopt some changes with the passage of time due to tough global competition. These types of changes not only affect the overall environment of an organization but also impact on employee's thinking and response toward organization results. Such changes may result an increasing trend toward employees turnover. The myth or success of service industry especially banking industry is based upon relationship with customers and when a loyal employee quits an organization then customers also quit that organization due to relationship with said employee. Now a day, it is big challenge for every bank to cut down the employee turnover rate that is so high in banking industry i.e. $9.1 \%$.

OC acts as backbone in order to reduce the employee turnover rate as both have reverse relationship. OC also helps in bringing positive changes in behavior of employees. The definition of OC is "Employees affiliation and connection with workplace" $(1,2)$. Dedicated people even never avoid sacrificing their private benefits for the goodwill of workplace (3). Loyal employees are always ready to create their strong relation with norms and objectives of organization $(1,4,5)$. Such employees think extra about the growth and welfare of organization as compare to others. Intension to leave the job or searching for new job, both have adverse relation with organizational commitment $(6$, 7). Furthermore, OC is positively related to Job satisfaction (8), attendance motivation (9).

There are a number of factors which have relationship with organizational commitment; in the literature many factors have been discussed to identify how these factors have relationship with organizational commitment like Employee

Muhammad Adnan Ashraf, Visiting lecture

University of the Punjab, Gujranwala Campus

Pakistan empowerment and Perceived organizational support. Employee empowerment is considered as an important element for organizational commitment (10). In service industry, competitive advantage can only be achieved through empowerment $(11,12,13,14,15)$. Perceived organizational support (POS) has direct relation with affective organizational commitment $(16,17)$. POS can be defined as "the workforce trust that employer considers their sacrifices and looks after them and fulfils their socioemotional needs (18)." POS is not only developed a better image for organization but also create strong binding between employees and employer (17). A positive relationship exists between POS and work attendance (17), job performance (17), citizenship behavior (19), Job satisfaction (20) and especially affective commitment (17). POS has negative relation with intentions to quit (21) and absenteeism (17).

Here, we are mainly work to see the influence of employee empowerment and perceived organizational support on Affective Commitment. The paper is organized in such a way: Section two will portray the literature on employee empowerment, perceived organizational support and organizational commitment and hypotheses development. After this, the research methodology is presented and result was shown by using different statistical techniques. At the end, the conclusion and limitations of the research were suggested.

\section{Literature review}

\section{A. Organizational Commitment (OC)}

Organizational commitment means "Emotional attachment of an employee with objectives and targets of an organization" (2). Several research works have found that absenteeism, turnover and organizational citizenship behavior are consequences of organizational commitment $(22,23,24,25)$. In addition, organizational commitment has positive relation with Job satisfaction (8), attendance motivation (9). Alexander Newman conducted research on different organizations of China and proved that Organizational commitment and POS have strong relationship (16). Robert Eisenberger proved that retention of employees is closely associated with POS and this retention promotes OC (27). Research conducted on employees of Lean production in Sri Lanka found that POS has direct relation with job involvement and negatively with willingness to job quit; these factors lead toward organizational commitment (28). According to Tsung Hsien Kuo that $\mathrm{OC}$ is achieved through employee empowerment, a research conducted in China in Information Technology industry (10) Employee empowerment has strong influence over job satisfaction on employees of hotel industry in Turkey (30). Job satisfaction leads toward organizational commitment. OC is strongly linked with EE and employee 
Proc. of the Fourth International Conference on Advances in Social Science, Management and Human Behaviour - SMHB 2016. Copyright (C) Institute of Research Engineers and Doctors. All rights reserved. ISBN: 978-1-63248-116-0 doi: 10.15224/ 978-1-63248-116-0-38

turnover has adverse relation with OC, a research conducted on workers of Lithuanian healthcare sector (31). Mayer and Allen (1997) explained that organizational commitment includes: Affective commitment----emotionally association of someone with objectives and targets of an organization. Continuance commitment---- An employee is not ready to quit the organization due to strong binding with co-workers. Normative commitment----not to leave the workplace due to some external pressure. Affective commitment is considered to be as inevitable among these three types of commitments and we are also working on it in this study.

\section{B. Employee Empowerment (EE)}

Empowerment is defined as "Ability to make decisions for the betterment of organization without getting permission from anyone else." (32). Empowerment in service industry means that an employee has the authority to find solutions of customer problems and to take suitable decisions without taking permission from supervisor (33). Hales and Klidas (1998), define empowerment as the name of sharing knowledge, information and power with juniors. Kanungo 1982 treats empowerment as an important tool to boost up the sense of self- efficacy in employees. Empowerment means internal motivation that has four different types i.e. sense, competence, choice and impact as Spreitzer (1995). Employee empowerment is an important tool to boost up the OC (10). Organizational commitment and employee empowerment have direct relation (36). According to Tsung Hsien Kuo et al., (2009) that OC is achieved through employee empowerment, a research conducted in China in Information Technology industry. Employee empowerment has a strong impact over job satisfaction on employees of hotel industry in Turkey (30). Job satisfaction leads toward organizational commitment. $\mathrm{OC}$ is strongly linked with EE and employee turnover has adverse relation with $\mathrm{OC}$, a research conducted on workers of Lithuanian healthcare sector (31). Team working boosts up the empowerment that further directs toward organizational commitment (37). Wiley (1999) established a link among locus of control, empowerment and organizational commitment. Empowerment is also acting as mediating for organizational commitment (39).

\section{Perceived Organizational Support (POS)}

Perceived organizational support (POS) has positive relationship with affective organizational commitment (16, 17). POS can be defined as "the workforce trust that employer considers their sacrifices and looks after them and fulfils their socio-emotional needs (18)." POS is not only developed a better image for organization but also create strong binding between employees and employer (17). A positive relationship exists between POS and work attendance (17), job performance (17), citizenship behavior [19], Job satisfaction (20) and especially affective commitment (17). POS has negative relation with intentions to quit (21) and absenteeism (17). Alexander Newman conducted research on different organizations of China and proved that Organizational commitment and POS have strong relationship (16). Robert Eisenberger proved that retention of employees is closely associated with POS and this retention promotes OC (27). Research conducted on employees of Lean production in Sri Lanka found that POS has direct relation with job involvement and negatively with willingness to job quit; these factors lead toward organizational commitment (28). POS is positively related with empowerment and job involvement, a research conducted in hospitals of china. (40). As a result, the researchers can pose following hypotheses:

H1: Employee empowerment has an influence on organizational commitment

H2: Perceived organizational support has an influence on organizational commitment

\section{Hypothetical Model}

The literature and already posed hypotheses have enabled the researchers to develop following figure 2.1 which demonstrated the relationship between employee empowerment (EE), perceived organizational support (POS) and organizational commitment (OC).

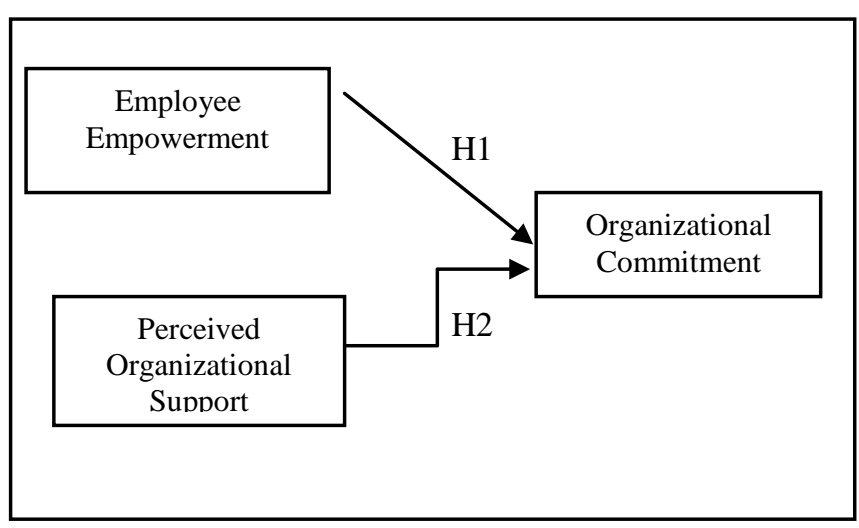

Figure: Hypothetical Model

\section{Research Methodology}

\section{A. Research Procedure and Sample Size}

In order to achieve the objectives of study, we used a questionnaire. This Questionnaire had two parts: first section elaborated the personal traits of participants such as gender, age, marital status, qualifications, position and job tenure. Second part consisted upon all the questions relating to our variables by using 5 point likert scale starting (1) strongly disagree and ending with (5) strongly agree i.e. employee empowerment was measured by twelve items taken from the scale developed by Spreitzer G.M (1995), perceived organizational support (POS) was measured by seventeen items from a scale developed by Eisenberger et al (1986) and affective commitment was measured by eight items from a scale developed by Mayer and Allen (1997).

There are 49 different banks working in Pakistan and among these banks Allied Bank Limited (ABL) had been selected. There are 15000 permanent employees in ABL and among these 153 had been selected as respondents by using random sampling technique.

\section{B. Demographics}

There were 116 male and 37 female respondents out of 153 of total participants, consisting upon $75.8 \%$ male and $24.2 \%$ female. Mostly the participants were having age between 26-30 years consisting of $58.8 \%$ of total sample. Further 
Proc. of the Fourth International Conference on Advances in Social Science, Management and Human Behaviour - SMHB 2016. Copyright (C) Institute of Research Engineers and Doctors. All rights reserved. ISBN: 978-1-63248-116-0 doi: 10.15224/ 978-1-63248-116-0-38

$23.5 \%$ of age $21-30$ years, $8.5 \%$ of 31 to 35 years, $5.9 \%$ of age $41-45$ years and only $3.3 \%$ of age between 36 to 40 years. Among the respondents $39 \%$ were married and remaining $61 \%$ were single. In addition, $3.3 \%, 30.7 \%$ and $66 \%$ respondents were undergraduate, graduate and post graduate respectively. Further, $31 \%$ respondents were enjoying managerial post and remaining $69 \%$ were on non manager positions.

At the end of first section, questions were asked about experience and job tenure and we acquired those 58 respondents have work experience 4-6 years (37.9\%) of total sample, 45 have job tenure 1-3 years and these were $29.4 \%$ of total respondents, 41 have work experience 7-10 years (26.8\%) of total sample and only 9 respondents have more than 10 years job tenure and their percentage is $5.9 \%$.

\section{Results}

In order to see the influence of employee empowerment and perceived organizational support on organizational commitment multiple regression analysis has been used. Further, reliability of survey instrument was measured by using Cronbach's Alpha

Table 1: Alpha's Values

\begin{tabular}{|l|l|l|c|}
\hline $\mathrm{Sr} \#$ & \multicolumn{1}{|c|}{ Variables } & Values & $\mathrm{A}$ \\
\hline 1 & Organizational Commitment (OC) & 8 & .772 \\
\hline 2 & Employee Empowerment (EE) & 12 & .781 \\
\hline 3 & $\begin{array}{l}\text { Perceived Organizational Support } \\
\text { (POS) }\end{array}$ & 17 & .911 \\
\hline & Total & 37 & .937 \\
\hline
\end{tabular}

Table 2: Model Summary

\begin{tabular}{|l|c|c|l|l|l|}
\hline Model & $\mathrm{R}$ & $\mathrm{R}^{2}$ & Adjusted $\mathrm{R}^{2}$ & $\begin{array}{c}\text { Std. Error } \\
\text { of the Estimate }\end{array}$ & Durbin-Watson \\
\hline 1 & $.856^{\mathrm{a}}$ & .733 & .729 & .40375 & 1.420 \\
\hline
\end{tabular}

Table 3: ANOVA

\begin{tabular}{|l|l|l|l|l|c|c|}
\hline \multicolumn{2}{|c|}{ Model } & $\begin{array}{c}\text { Sum of } \\
\text { Squares }\end{array}$ & df & MeanSquare & F & Sig. \\
\hline \multirow{2}{*}{1} & Regression & 67.055 & 2 & 33.527 & 205.667 & $.000^{\mathrm{a}}$ \\
\cline { 2 - 7 } & Residual & 24.453 & 150 & .163 & & \\
\cline { 2 - 7 } & Total & 91.507 & 152 & & & \\
\hline
\end{tabular}

Table 4: Coefficients

\begin{tabular}{|c|c|c|c|c|c|c|c|}
\hline \multirow[b]{2}{*}{ Model } & \multicolumn{2}{|c|}{$\begin{array}{c}\text { Unstandardiz } \\
\text { ed } \\
\text { Coefficients }\end{array}$} & \multirow{2}{*}{$\begin{array}{l}\text { Standardized } \\
\text { Coefficients }\end{array}$} & \multirow[b]{2}{*}{$\mathrm{t}$} & \multirow[b]{2}{*}{ Sig. } & \multicolumn{2}{|c|}{$\begin{array}{c}\text { Collinearity } \\
\text { Statistics }\end{array}$} \\
\hline & B & 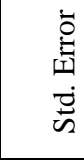 & & & & 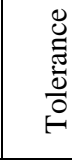 & VIF \\
\hline (Constant) & .475 & .200 & & 2.371 & .019 & & \\
\hline $\mathrm{EE}$ & .066 & .084 & .050 & .789 & .431 & .446 & 2.242 \\
\hline POS & .844 & .065 & .818 & 12.947 & .000 & .446 & 2.242 \\
\hline
\end{tabular}

Table 1 illustrated the reliability test of used questionnaire. By using the Cronbach's Alpha, we have obtained the values of individual variable as well overall. The overall value is 937. If value of Cronbach's Alpha is greater than .70 then the used questionnaire is strongly reliable. [41] so, we can say that questionnaire is strongly reliable which crosses benchmark mentioned by Hair et al by totally as of each individual variable, i.e. organizational commitment (.702), employee empowerment (.781) and perceived organizational support (.911).

Table 2 showed the following: R square calculated the total variation in DV (Organizational Commitment) under presence of both IV (Employee Empowerment and Perceived Organizational Support) and it is proved that both independent variables have $73.3 \%$ influence on organizational commitment; as (.733) table value of $\mathrm{R}$ square showing an excellent picture. In order to calculate the positivity, negativity and zero type of correlation, we have used Durbin Watson and found that Durbin Watson is 1.420 that is lesser from 2 which showed positive correlation among studied variables.

Third table 3 was used to calculate the ANOVA in order to see the level of significance. Result showed that significance level is 0.000 that is quite lesser from 0.05 and hence proved that impact of employee empowerment and perceived organizational support on organizational commitment is strong.

Last table 4 depicted the beta values of studied variables; the purpose of beta values is to calculate the impact of each independent variable on dependent variable singly and it is examined that perceived organizational support has also high impact on organizational commitment with beta value .818 which means that $81.8 \%$ variation in organizational commitment is occurred due to perceived organizational support in banking industry and its level of significance is also at .000 so $\mathrm{H} 2$ is proved. Employee Empowerment that is second independent variable has beta value .050 . It shows that $5.0 \%$ variation in organizational commitment is occurred due to employee empowerment which is significance at .431 which is not supporting $\mathrm{H} 1$ under this study. So results show that in this study perceived organizational support has strong influence on organizational commitment but employee empowerment is not influencing organizational commitment under this study. Besides this, Collinearity was also calculated and found that in data no multi-Collinearity existed in data, as results showed that the tolerance .446 (smaller than 5) and VIF 2.242 (smaller than 10). In a net shell it can be said that POS has strong influence on organizational commitment, more over EE also has positive relationship with organizational commitment but in this study it has little influence on organizational commitment.

\section{Iv. Conclusion, Limitations \& Future Research}

This study is conducted with the aim to find the impact of Employee Empowerment and Perceived Organizational Support on Organizational Commitment among employees of banking industry. Employees of Allied Bank Limited 
Proc. of the Fourth International Conference on Advances in Social Science, Management and Human Behaviour - SMHB 2016.

Copyright (C) Institute of Research Engineers and Doctors. All rights reserved.

ISBN: 978-1-63248-116-0 doi: 10.15224/ 978-1-63248-116-0-38

were selected as respondents and questionnaire was used to collect the data by using random sampling. Findings revealed that both employee empowerment and perceived organizational support positively influence the organizational commitment. Multiple Regression shows that perceived organizational support has strong influence of organizational commitment in $\mathrm{ABL}$ while employee empowerment has week influence on commitment level among employees of ABL. Results show when empowerment and organizational support is given to employees then they are more satisfied and their commitment level boost up and hence beneficial for ABL as well as presumably the whole banking sector of Pakistan.

Furthermore, in order to get more accurate and precise results more banks can be included in study sample with larger sample size. As this study is financially constrained which is only limited to banking sector, while other sectors can also be added in near future.

\section{v. Practical Implication}

This research is also beneficial for the management of Allied Bank Limited that if they want to reduce the employee turnover rate and want to create more committed employees then management must empower the employees as well giving them organizational support. This will not only motivate the employees but also create the better corporate image.

\section{References}

[1] Hunt S.D., Wood, R.V and Chonko, L.B. Corporate ethical values and organizational commitment in marketing. Journal of marketing, 54: 56-72 (1989).

[2] Mayer, J.P and Allen, N.J. Commitment in work place: theory, research and application. Sage, Thousand Oaks, CA. (1997).

[3] Jaworski, BJ. And Kotli, A.K. Market orientation: antecedent and consequences. Journal of Marketing. 57: 53-70 (1993).

[4] Buchanan, B. Building Organizational Commitment: the socialization of managers in work organization, Administration Service Quarterly. 19(4), 533-46 (1974)

[5] Hrebiniak, L. and Alutto, J.A. Personal and role related to factors in the development of organizational commitment. Administration Service Quarterly. 17(3), 555-72 (1972).

[6] Colbert, A. And Kwon, I.W. Factors related to organizational commitment of college and university auditors. Journal of Managerial Issues. 12(4), 484-501 (2000)

[7] Quarles, R. An examination of promotion opportunities and evaluation criteria as mechanism for affecting internal auditor commitment, job satisfaction and turnover intensions. Journal of Managerial Issues. 6(2), 176-94 (1994).

[8] Tsai, M.T. and Huang, C.C. The relationship among ethical climate types, facets of job satisfaction, and three components of organizational commitment: a study of nurses in Taiwan. Journal of Business ethics. Vol 80, 565-81 (2008).

[9] Breedijk, M., de Gilder, D. and Schuyt, T. Gauging the results of employee volunteering. Corporate Responsibility Management. 2(1), 20-23 (2005)

[10] Janssen, O. The barrier effect of conflict with superiors in the relationship between employee empowerment and organizational commitment. Work \& Stress. Vol. 18 No. 1, 56-65 (2004).

[11] Conger, J. and Kanungo, R. The empowerment process: integrating theory and practice. Academic of Management Review. Vol. 13 No.3 471-82 (1988).

[12] Kanungo, R. Management of job and work involvement. Journal of Applied Psychology. Vol, 67, 341-349 (1982).

[13] Bowen, D. and Lawler, E.E. The empowerment of service workers: what, why, how and when. Sloan Management Review. Vol. 23 No. 3, 31-39 (1992)
[14] Lashley, C. Research issues for employee empowerment in hospitality organizations. International Journal of Hospitality Management. Vol. 15 No.4, 333-46 (1996).

[15] Quinn, R.E. and Spreitzer, G.M. The road to empowerment seven questions every leader should consider. Organizational Dynamics. Vol. 25 No. 2 37-49 (1997).

[16] Alexander Newman, Rani Thanacoody \& Wendy Hui. The effects of perceived organizational support, perceived supervisor support and intra organizational network resources on turnover intentions. Personnel Review 41 (1), 56-72 (2012).

[17] Eisenberger, R., Fasolo, P., \& David- LaMastro, V. Perceived organizational support and employee diligence, commitment and innovation. Journal of Applied Psychology, 75, 51-59 (1990).

[18] Eisenberger, R., Huntington, R., Hutchison, S., \& Sowa, D. Perceived organizational support. Journal of Applied Psychology, 71, 500-507 (1986).

[19] Shore, L.M. and Wayne, S.J. Commitment and employee behaviour: Comparison of affective commitment and continuance commitment with perceived organization support. Journal of applied Psychology. Vol.78, 774-80 (1993).

[20] Eisenberger, R., Cummings, J., Armeli, S. \& Lynch, P. Perceived organization support, discretionary treatment and job satisfaction. Journal of Applied Psychology. Vol.82, 812-820 (1997).

[21] Wayne, S.J. Shore, L.M. and Liden, R.C. Perceived organization support and leader-member exchange a social exchange perspective. Academic of Management Journal. Vol.40, 82-111 (1997).

[22] Farrell, D., and Stamm, C. Mata analysis of the correlates of employee absence. Human Relations. Vol, 41, 221-27 (1988).

[23] Mathieu, J., and Zajac, D. A review and Meta analysis of the antecedents, correlates, and consequences of organization commitment. Psychological Bulletin. Vol, 1 61-89 (1990).

[24] Morrow, P. The theory and Measurement of work commitment. JAI Press, Greenwich, CT (1993).

[25] Wright, T. And Bonett, D. The moderating effects of employee tenure on the relations between organization commitment and organization performance a Meta Analysis. Journal of Applied Psychology. Vol, 87, 1183-90 (2002).

[26] Robert Eisenberger, Florence Stinglhamber, Christian Vandenberghe, Ivan, L. Sucharski and Linda Rhoades. Perceived supervisor support: contribution to perceived organization support and employee retention. Journal of Applied Psychology. Vol,87, No. 3 565-573 (2002).

[27] David G. Allen, Lynn M. Shore \& Rodger W. Griffeth. The role of perceived organizational support and supportive human resource practices in the turnover process. Journal of management. 29 (1), 99118 (2002).

[28] Dharmasri Wickramasinghe, Vathsala Wickramasinghe. Perceived organizational support, job involvement and turnover intention in lean production in Sri Lanka. Int. J. Adv. Manuf Technol. 55 (1), 817-830 (2011).

[29] Tsung H. Kuo, Li An Ho, Chinho Lin \& Kuei K. Lai. Employee empowerment in a technology advanced work environment. Industrial management and data systems 110 (1), 24-42 (2009).

[30] Elbeyi Pelit, Yuksel Ozturk \& Yalcin Arslanturk. The effects of employee empowerment on employee job satisfaction. International journal of contemporary hospitality management 23 (6), 784-802 (2010).

[31] Ruta Kazlauskaite, Ilona Buciuniene \& Linas Turauskas. Building employee commitment in the hospitality industry. Baltic journal of management. 1 (3), 300-314 (2006).

[32] Luthans, F. Organization Behavior. 5th edition. Irwin/ McGraw- Hill, Boston MA (1998).

[33] Lovelock, C., and Wright, L. Principles of service marketing and management. Prentice-Hall, Upper Saddle, River, NJ. (1999)

[34] Hales, C. and Kalidas, A. Empowerment in five-star hotels: choice, voice or rhetoric? International journal of contemporary hospitality management. Vol, 10 No. 3 88-95 (1998).

[35] Spreitzer, G.M. Psychological Empowerment in the workplace: dimensions, measurement and validations. Academic of Management Journal. Vol,38 No. 5, 1442-65 (1995).

[36] Bhatnagar, J. Predictors of organizational commitment in India: Strategic HR roles, organizational learning capability and psychological empowerment. The International Journal of Human Resource Management. Vol, 18, No.1, 1782-812 (2007).

[37] Huang, X., Shi, K., Zhang, Z., and Cheung, Y.L. The impact of participative leadership behavior on psychological empowerment and organizational commitment in Chinese state- owned enterprises: the 
Proc. of the Fourth International Conference on Advances in Social Science, Management and Human Behaviour - SMHB 2016.

Copyright (C) Institute of Research Engineers and Doctors. All rights reserved.

ISBN: 978-1-63248-116-0 doi: 10.15224/ 978-1-63248-116-0-38

moderating role of organizational tenure. Asia Pacific Journal of Management. Vol. 23, No.3, 345-67 (2006).

[38] Wiley, D.M. Impact of locus of control and empowerment on organizational commitment, doctoral dissertation, United States International University, San Diego, CA. (1999).

[39] Lane, C.E. The empowerment based model of organizational commitment: Implication for the public sector. DPA dissertation, University of Southern California. Los Angeles. CA (1998).

[40] Chun-Fan Chiang, Tsung-Sheng Hsieh. The impacts of perceived organizational support and psychological empowerment on job performance: The mediating effects of organization citizenship behavior. International Journal of Hospitality Management. Vol. 31, 180-190 (2012).

[41] Hair, J.F., R.E. Anderson, R.LTatham and W.C. Black. Multivariate data analysis. Fifth edition, New Jersey, Prentice-Hall Inc. Upper Saddle River, NJ (1998).

About Author (s):

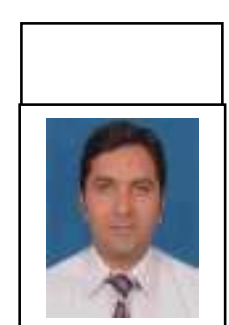

I am Muhammad Adnan Ashraf and acting as Business Development Manager in Banking industry as well as visiting Lecturer in Punjab University. This research paper is a real time case study which I am facing with my job and through this research paper; I want to contribute body of knowledge in order to solve this problem which is facing banking industry of Pakistan. 